\title{
NanoSIMS and EPMA dating of lunar zirconolite
}

\author{
Nian Wang ${ }^{1,2+}$, Qian Mao ${ }^{3 \dagger}$, Ting Zhang ${ }^{1,2}$, Jialong Hao ${ }^{1}$ and Yangting Lin ${ }^{1 *}(\mathbb{D}$
}

\begin{abstract}
Zirconolite is a common Zr-rich accessary mineral in mafic rocks. It is also an ideal $\mathrm{U}-\mathrm{Pb} / \mathrm{Pb}-\mathrm{Pb}$ chronometer because it commonly contains high $\mathrm{U}$ content (mostly $0.1-10 \mathrm{wt} \%$ ) and negligible initial Pb. However, zirconolite is usually very small (e.g., $\sim 1 \mu \mathrm{m}$ in width) in lunar rocks, requiring a high spatial resolution analysis. We analyzed a single, large $(25 \mu \mathrm{m} \times 20 \mu \mathrm{m})$ grain of zirconolite in lunar meteorite NWA 4485 using Pb-Pb dating by NanoSIMS and $\mathrm{U}-\mathrm{Th}-\mathrm{Pb}$ dating by EPMA. The resultant $\mathrm{U}-\mathrm{Th}-\mathrm{Pb}$ age is $4540 \pm 340 \mathrm{Ma}(2 \sigma)$ with a spatial resolution of $1.3 \mu \mathrm{m}$. The $\mathrm{Pb}-\mathrm{Pb}$ age by NanoSIMS is $4348.5 \pm 4.8 \mathrm{Ma}(2 \sigma)$ with a spatial resolution of $\sim 2 \mu \mathrm{m}$, consistent with the age of $4352 \pm 10 \mathrm{Ma}$ and $4344 \pm 14 \mathrm{Ma}$ reported in the same meteorite and its paired meteorite NWA 4472. Although $\mathrm{U}-\mathrm{Th}-\mathrm{Pb}$ age is somewhat older, it still includes the NanoSIMS results within the analytical uncertainty. This work demonstrates the potential application of the combined EPMA dating and REE analysis of lunar zirconolite, with the benefits of high spatial resolution, non-destructive, and readily accessibility of the instrument. The precision of the EPMA dating $(7.6 \%, 2 \sigma)$ can be improved by increasing the counting time for $\mathrm{Pb}, \mathrm{U}$ and $\mathrm{Th}$. We expect to apply this EPMA technique for a quick and non-destructive age survey and geochemical study of zirconolite grains from the lunar mare basalts newly returned by Chang'E-5 mission which landed on a very young (1.2-2.0 Ga by crater-counting chronology) basalt unit in Procellarum KREEP Terrain.
\end{abstract}

Keywords: Zirconolite, Chemical age, Lunar sample, NWA 4485, Chang'E-5, Lunar basalt

\section{Introduction}

Zirconolite $\left(\mathrm{CaZrTi}_{2} \mathrm{O}_{7}\right)$ has been recognized as a fairly common accessory mineral first in terrestrial rocks (Williams and Giere 1996) and then in lunar basaltic rocks from Apollo 11 and 12 (Lovering and Wark 1971; Wark et al. 1973). Zirconolite usually contains high $U$ (mostly 0.1-10 wt\%) with negligible common $\mathrm{Pb}$ (Williams and Giere 1996), making it a potential U-Pb chronometer. Since the work by Rasmussen and Fletcher (2004), it has been demonstrated as an ideal mineral for $\mathrm{U}-\mathrm{Pb}$ geochronology using sensitive high-resolution ion microprobe (SHRIMP) and secondary ion mass spectrometry (SIMS) techniques with reliable age precision (Downes et al. 2016; Norman and Nemchin 2014; Rasmussen et al.

\footnotetext{
*Correspondence: linyt@mail.iggcas.ac.cn

${ }^{\dagger}$ Nian Wang and Qian Mao contributed equally to this work

1 Key Laboratory of Earth and Planetary Physics, Institute of Geology

and Geophysics, Chinese Academy of Sciences, Beijing 100029, China

Full list of author information is available at the end of the article
}

2008 2009; Wu et al. 2010; Zhang et al. 2010). Meanwhile, the in situ $\mathrm{U}-\mathrm{Pb}$ geochronology of zirconolite has also demonstrated that it yields $\mathrm{Pb}-\mathrm{Pb}$ ages that are more precise than those obtained from coexisting zircon and baddeleyite (Rasmussen and Fletcher 2004).

Lunar zirconolite was commonly reported as a ubiquitous trace mineral in the late stage mesostasis of lunar mare basalt (Day et al. 2006; Rasmussen et al. 2008; Wark et al. 1973; Zeigler et al. 2005). It usually contains lower $\mathrm{U}$ and Th contents than terrestrial zirconolite and therefore less degree of metamictization and $\mathrm{Pb}$-loss caused by alpha-decay damage. However, most lunar zirconolite grains are always fine-grained or elongated "strings", ranging in shapes from laths to tubular rods (Rasmussen et al. 2008; Seddio et al. 2013). They rarely grow up to $10 \mu \mathrm{m}$ in size and frequently appear as needle-like strings with length up to tens of $\mu \mathrm{m}$ but width less than $2 \mu \mathrm{m}$ (Rasmussen and Fletcher 2004; Seddio et al. 2013). This typical morphology of zirconolite makes most occurrences too small for traditional analyses like SIMS 
or SHRIMP dating. Therefore, higher lateral resolution secondary ion spectrometer like CAMECA NanoSIMS $50 \mathrm{~L}$ is more appropriate for small size zirconolite dating, which can recently achieve the submicron spatial resolution for $\mathrm{Pb}-\mathrm{Pb}$ dating but with significant depth effect after equipped with the new radio-frequency iron source (Hao et al. 2021).

For traditional ion microprobes, such as SIMS, SHRIMP, and NanoSIMS, their major disadvantage is that they are destructive for zirconolite grains when analyzing. In addition, only limited elements or isotopes concentrations can be acquired at once by ion microprobes due to their limited detectors. For precious lunar sample, such as the recently returned Chang'E-5 lunar soil, damage-free and more effective dating method like EPMA U-Th-Pb chemical dating coupled with REE measurements is very useful for a quick prelude dating survey before destructive analyses. Regarding EPMA chemical dating, it was first published in Bowles (1990) and used on uraninite $\left(\mathrm{UO}_{2}\right)$, and then developed for use on other U-bearing minerals, such as monazite, zircon, and xenotime in Suzuki and Adachi (1991a, b). Later, numerous publications have demonstrated its usage in both terrestrial and lunar rocks, and analytical techniques to obtain the best result were also presented in these studies (Bowles 2015; Chatterjee et al. 2017; Cocherie and Legendre 2007; Cross et al. 2011; Downes et al. 2016; Hazarika et al. 2017; Montel et al. 1996; Pyle et al. 2005; Seddio et al. 2014, 2013; Suzuki et al. 1994; Yonemura et al. 2013). Among these work, several studies have tried to apply EPMA chemical dating to zirconolite, such as: Rajesh et al. (2006) reported EPMA dating of zirconolite from terrestrial samples, assuming that all $\mathrm{Pb}$ analyzed are radiogenic; Seddio et al. (2013) used EPMA to date the zirconolite from Apollo 12,032 granite. Although the accuracy of the EPMA dating is considered poor compared to the isotopic ages, its potential superior spatial resolution up to $1 \mu \mathrm{m}$, good integrating of minor elements and age information, non-destructive, and easier access of the facility, make EPMA chemical dating a complementary technique to SIMS dating (Hazarika et al. 2017; Montel et al. 1996).

To verify the reliability of EPMA dating of lunar zirconolite, a KREEP-rich lunar meteorite NWA 4485 (Arai et al. 2009) was used for study, which is a polymict regolith breccia and paired with NWA 4472 (Joy et al. 2011). Consistent with its high KREEP contents, there are many Zr-rich minerals including zircon, baddeleyite, and zirconolite that are suitable for dating measurements in NWA 4485 . A single, large $(25 \mu \mathrm{m} \times 20 \mu \mathrm{m})$ grain of zirconolite was found and analyzed using $\mathrm{Pb}-\mathrm{Pb}$ dating by NanoSIMS and U-Th-Pb dating by EPMA, and then the result of chemical age is compared with that of $\mathrm{Pb}-\mathrm{Pb}$ isotope age.

\section{Methods}

A polished section $\left(1.2 \times 1 \mathrm{~cm}^{2}\right)$ of NWA 4485 was prepared from a chip of the meteorite, and it was carbon coated. The section was observed in backscatter electron (BSE) images using a field emission scanning electron microscope NOVA NANOSEM450 equipped with a Gatan cathodoluminescence $(\mathrm{CL})$ detector at Institute of Geology and Geophysics, Chinese Academy of Sciences (IGGCAS). The operating conditions were $15 \mathrm{kV}$ accelerating voltage and $3.2 \mathrm{nA}$ beam current. Quantitative analysis of zirconolite was determined using a Cameca SXFiveFE electron probe microanalyzer (EPMA) equipped with wavelength-dispersive X-ray spectrometers (WDS) at IGGCAS. The accelerating voltage of $20 \mathrm{kV}$ and a beam current of $70 \mathrm{nA}(\sim 1 \mu \mathrm{m}$ in diameter $)$ were used. During data acquisition, peak counting time for each element is the same as their background counting time: $\mathrm{Ca}\left(K_{\alpha}, 10 \mathrm{~s}\right), \mathrm{Ti}\left(K_{\alpha}, 10 \mathrm{~s}\right)$, Fe $\left(K_{\alpha}, 20 \mathrm{~s}\right), \mathrm{Y}\left(L_{\alpha}\right.$, $20 \mathrm{~s}), \mathrm{Zr}\left(L_{\alpha}, 20 \mathrm{~s}\right) ; \mathrm{Mg}\left(K_{\alpha}, 30 \mathrm{~s}\right), \operatorname{Al}\left(K_{\alpha}, 30 \mathrm{~s}\right), \mathrm{Si}\left(K_{\alpha}\right.$, $30 \mathrm{~s}), \mathrm{La}\left(L_{\alpha}, 30 \mathrm{~s}\right), \mathrm{Ce}\left(L_{\alpha}, 30 \mathrm{~s}\right), \mathrm{Nd}\left(L_{\alpha}, 30 \mathrm{~s}\right), \operatorname{Sm}\left(L_{\beta}\right.$, $30 \mathrm{~s}), \mathrm{Gd}\left(L_{\alpha}, 30 \mathrm{~s}\right), \mathrm{Pb}\left(M_{\alpha}, 30 \mathrm{~s}\right)$, Th $\left(M_{\alpha}, 100 \mathrm{~s}\right)$, and U $\left(M_{\beta}, 100 \mathrm{~s}\right)$. Additionally, $\mathrm{Pb}$, Th, and $\mathrm{U}$ lines are all measured on LPET crystals. Overlapping correction method was used for interference correction according to the method reported by Pyle et al. (2005). Corrections for the interference of $\mathrm{Y} L_{\gamma 2,3}$ on $\mathrm{Pb} M_{\alpha}, \operatorname{Sm} L_{\beta 7}$ on $\mathrm{U} M_{\beta}$, and $\mathrm{Th} M_{\zeta 1}$ on $\mathrm{Pb} M_{\alpha}$ were precisely carried out. Due to the small correction factor of $\mathrm{Pb} M_{\alpha} / \mathrm{Th} M_{\tau_{1}}$ and low Th concentration in NWA 4485 zirconolite, the interference of $\mathrm{Th} M_{\zeta 1}$ on $\mathrm{Pb} M_{\alpha}$ was too small to affect the $\mathrm{Pb}$ concentration and can be negligible. The full range WDS spectra acquired with TAP, LPEP, and LiF diffractors are shown in Additional file 1: Fig. S1. The standard materials used for $\mathrm{U}$, Th were both synthesized glasses: $7.40 \mathrm{wt} \% \mathrm{Al}$, $27.25 \mathrm{wt} \% \mathrm{Si}, 15.76 \mathrm{wt} \% \mathrm{Ca}, 5.18 \mathrm{wt} \% \mathrm{Th}$, and $44.63 \mathrm{wt} \%$ O for Th; $7.42 \mathrm{wt} \% \mathrm{Al}, 27.52 \mathrm{wt} \% \mathrm{Si}, 16.07 \mathrm{wt} \% \mathrm{Ca}, 3.85$ $\mathrm{wt} \% \mathrm{U}$, and $44.90 \mathrm{wt} \% \mathrm{O}$ for U. Natural crocoite $\left(\mathrm{PbCrO}_{4}\right)$ was used as $\mathrm{Pb}$ standard material. Other synthetic and natural standards were periclase $(\mathrm{MgO})$ for $\mathrm{Mg}$, corundum $\left(\mathrm{Al}_{2} \mathrm{O}_{3}\right)$ for $\mathrm{Al}$, wollastonite $\left(\mathrm{CaSiO}_{3}\right)$ for $\mathrm{Si}$ and $\mathrm{Ca}$, rutile $\left(\mathrm{TiO}_{2}\right)$ for $\mathrm{Ti}$, hematite $\left(\mathrm{Fe}_{2} \mathrm{O}_{3}\right)$ for $\mathrm{Fe}$, yttrium aluminum garnet $\left(\mathrm{Y}_{3} \mathrm{Al}_{5} \mathrm{O}_{12}\right)$ for $\mathrm{Y}$, and $10 \% \mathrm{REE} \mathrm{Si}-\mathrm{Al}-$ $\mathrm{Ca}-\mathrm{O}$ glasses for $\mathrm{La}, \mathrm{Ce}, \mathrm{Nd}, \mathrm{Sm}$ and $\mathrm{Gd}$, respectively. Detection limits are $30-50 \mathrm{ppm}$ for $\mathrm{Mg}, \mathrm{Al}, \mathrm{Si}, \mathrm{Ca}$ and Ti, 70-90 ppm for Fe, Th and U, 110-120 ppm for $Y$ and Gd, $130 \mathrm{ppm}$ for $\mathrm{Pb}, 220 \mathrm{ppm}$ for Zr, 150-170 ppm for $\mathrm{La}, \mathrm{Ce}$ and Nd, $300 \mathrm{ppm}$ for Sm. The Phi-Rho-Z matrix correction were applied for all data (Merlet 1994). In addition, Monte Carlo simulation of electron scattering 
in zirconolite was generated using Casino (Drouin et al. 2007 ) at accelerating voltage of $20 \mathrm{kV}$. The density of zirconolite is defined as $4.8 \mathrm{~g} / \mathrm{cm}^{3} .1 \times 10^{4}$ electron trajectories were calculated and used for displaying images. The resultant spatial resolution for our EPMA analyses is shown in Additional file 1: Fig. S2. We acquired the smallest interaction volume of electrons and generation volume of X-rays of $1.3 \mu \mathrm{m}$ diameter when the focused beam size is used. The corresponding $\mathrm{YZ}$ energy distribution shows $95 \%$ of energy are distributed less than $1.5 \mu \mathrm{m}$ in depth.

Following the method of Montel et al. (1996) for monazite, we calculated the chemical age of zirconolite, assuming that all the $\mathrm{Pb}$ is radiogenic. This assumption is verified by the negligible $\mathrm{Pb}^{204} / \mathrm{Pb}^{206}$ ratio in our NanoSIMS analyses in Sect. 3.3. Given this assumption, the amount of $\mathrm{Pb}$ produced is the sum of the $\mathrm{Pb}$ from the decay of both $U$ and Th:

$$
\begin{aligned}
\mathrm{Pb}= & \frac{T h}{232}\left(e^{232} t-1\right) 208+0.9928 \frac{U}{238.04}\left(e^{238} t-1\right) 206 \\
& +0.0072 \frac{U}{238.04}\left(e^{235} t-1\right) 207
\end{aligned}
$$

where $\mathrm{Pb}, \mathrm{Th}, \mathrm{U}$ are in $\mathrm{ppm}$, and $\lambda^{232}$ $\left(4.9475 \times 10^{-11}\right.$ year $^{-1}$; Steiger and Jäger 1977), $\lambda^{235}$ $\left(9.8485 \times 10^{-10}\right.$ year $^{-1}$; Steiger and Jäger 1977$)$, and $\lambda^{238}$ $\left(1.55125 \times 10^{-10}\right.$ year $^{-1}$; Steiger and Jäger 1977) are the radioactive decay constants for ${ }^{232} \mathrm{Th},{ }^{235} \mathrm{U}$ and ${ }^{238} \mathrm{U}$, respectively.

Because of the lack of zirconolite references, the fractionation between $\mathrm{U}$ and $\mathrm{Pb}$ during the SIMS analysis cannot be calibrated. Instead, since the instrumental mass fractionation (IMF) of $\mathrm{Pb}$ isotopes is negligible (Yang et al. 2012), $\mathrm{Pb}-\mathrm{Pb}$ ages of the zirconolite can be measured without $\mathrm{U}-\mathrm{Pb}$ calibration. Therefore, $\mathrm{Pb}-\mathrm{Pb}$ dating was carried out on the same zirconolite grain by a CAMECA NanoSIMS 50L at IGGCAS, following the method for $\mathrm{Pb}-\mathrm{Pb}$ dating (Yang et al. 2012). The $\mathrm{O}^{-}$ primary beam was accelerated at $16 \mathrm{kV}$ with a current of $\sim 500 \mathrm{pA}$ and a beam size of $\sim 1.7 \mu \mathrm{m}$ in diameter. In order to achieve the maximum spatial resolution, the scanning off mode was used (Yang et al. 2012). Magnetic peak-switching mode was applied for the $\mathrm{Pb}-\mathrm{Pb}$ dating, and four magnetic fields were used in the following sequence: $\mathrm{B} 1$ for $\mathrm{Pb}$ background (203.5), B2 for ${ }^{204} \mathrm{~Pb}, \mathrm{~B} 3$ for ${ }^{96} \mathrm{Zr},{ }^{206} \mathrm{~Pb},{ }^{238} \mathrm{U},{ }^{232} \mathrm{Th}^{16} \mathrm{O},{ }^{238} \mathrm{U}^{16} \mathrm{O}_{2}$, and $\mathrm{B} 4$ for ${ }^{89} \mathrm{Y}$ and ${ }^{207} \mathrm{~Pb}$, among which lead background (203.5) and $\mathrm{Pb}$ isotopes $\left({ }^{204} \mathrm{~Pb},{ }^{206} \mathrm{~Pb},{ }^{207} \mathrm{~Pb}\right)$ were measured with the same EM\#4 detector. Before data acquisition, the sample surface was pre-sputtered by rastering the beam over 3 $\times 3 \mu \mathrm{m}^{2}$ area for $3 \mathrm{~min}$ in order to remove the surface contamination of terrestrial common $\mathrm{Pb}$. M257 zircon $\left({ }^{206} \mathrm{~Pb} /{ }^{238} \mathrm{U}\right.$ age $\left.=561.3 \mathrm{Ma}\right)$ and Phalaborwa baddeleyite $\left({ }^{207} \mathrm{~Pb} /{ }^{206} \mathrm{~Pb}\right.$ age $\left.=2059.6 \mathrm{Ma}\right)$ references (Yang et al. 2012) were measured to assess the potential drift of the instrument during the analytical session. Measured ${ }^{204} \mathrm{~Pb} /{ }^{206} \mathrm{~Pb}$ ratios were used for the correction of common $\mathrm{Pb}$ based on the two-stage evolution model of Stacey and Kramers (1975). Uncertainties of individual analysis are reported at 1 sigma level. Weighted average $\mathrm{Pb}-\mathrm{Pb}$ age was processed using Isoplot program (Ludwig 2003) and quoted at 2 sigma level.

\section{Results}

\subsection{Occurrence of zirconolite}

Zirconolite is an accessory mineral in NWA 4485. It appears as light gray and is less reflective than ilmenite and troilite, but more reflective than zircon under reflected light microscope. A relatively large grain of zirconolite $(25 \mu \mathrm{m} \times 20 \mu \mathrm{m}$ in size $)$ was identified as a mineral fragment in the regolith matrix of NWA 4485 (Fig. 1), surrounded by pyroxene, plagioclase and silicate melts (Fig. 1a). SEM and CL images of the zirconolite grain (Fig. 1b, c) revealed no compositional zoning or other internal features.

\subsection{EPMA quantitative analysis of zirconolite}

Major and minor composition of zirconolite Five EPMA analyses were carried out on the zirconolite grain. The quantitative analyses do not show significant variation from the core to the rim, confirming the homogeneous BSE and CL images. The EPMA results and the formulas of cations calculated based on 7 atoms of oxygen are given in Table 1. It contains $36.4 \mathrm{wt} \% \mathrm{ZrO}_{2}, 35.0 \mathrm{wt} \%$ $\mathrm{TiO}_{2}, 7.90 \mathrm{wt} \% \mathrm{CaO}, 5.80 \mathrm{wt} \% \mathrm{FeO}$, within the range of other zirconolite grains reported from lunar samples (Norman and Nemchin 2014; Rasmussen et al. 2008; Seddio et al. 2013) and terrestrial mafic igneous intrusions (Giere et al. 1998; Williams and Giere 1996). The $\mathrm{U}$, Th, and $\mathrm{Pb}$ average concentrations of this grain were $0.21 \pm 0.01 \mathrm{wt} \%, 0.56 \pm 0.01 \mathrm{wt} \%$, and $0.43 \pm 0.02$ $w t \%$, respectively. In addition, the concentrations of five REEs ( $\mathrm{La}, \mathrm{Ce}, \mathrm{Nd}, \mathrm{Sm}, \mathrm{Gd}$ ) and $\mathrm{Y}$ in the zirconolite were measured. Europium was below the detection limit (0.02 wt\%) in all analysis, which resulted in a negative Eu anomaly (Fig. 2). The CI-normalized REEs and Y pattern is plotted in Fig. 2, with Y locating between Ho and Er (Korotev 1996; Seddio et al. 2013). LREE concentrations are relatively lower than those of middle-REE, increasing from $3800 \times$ CI for La to $33,000 \times$ CI for Gd. The CI-normalized Y concentration $(22,500$ $\times \mathrm{CI}$ ) is slightly lower than that of Gd. The chondritenormalized REE pattern of zirconolite in NWA 4485 is characteristically convex and parallel to those of Apollo lunar zirconolites (Fig. 2) which show strong enrichment of REE $(\mathrm{La} 3834 \times \mathrm{CI}$, Y 22,500 × CI) in Apollo 
10,047 (Rasmussen et al. 2008). The other minor elements are $\mathrm{MgO}(0.44 \mathrm{wt} \%), \mathrm{Al}_{2} \mathrm{O}_{3}(0.52 \mathrm{wt} \%)$ and $\mathrm{SiO}_{2}$ (0.16 wt\%). Low analysis totals reflect the presence of other elements probably including $\mathrm{Nb}$, Ta, and HREEs.

EPMA Chemical dating of zirconolite Following the method of Montel et al. (1996), we calculated the chemical ages for the zirconolite EPMA analyses using their $\mathrm{Th}, \mathrm{U}$, and $\mathrm{Pb}$ concentrations listed in Table 1 . Five analyses yield a weighted mean age of $4540 \pm 340 \mathrm{Ma}(2 \sigma)$ with mean square weighted deviation $(\mathrm{MSWD})=0.17$ and probability $=0.96$ (Fig. 3 ).

\subsection{NanoSIMS Pb-Pb dating}

We carried out two NanoSIMS $\mathrm{Pb}-\mathrm{Pb}$ analyses on the zirconolite grain and the results are listed in Table 2. It shows that the zirconolite contains minimal common $\mathrm{Pb}$ with measured ${ }^{204} \mathrm{~Pb} /{ }^{206} \mathrm{~Pb}$ ratios less than $10^{-5}$ $\left(\mathrm{f}_{206}<10^{-6}\right)$. The analytical uncertainty is rather small

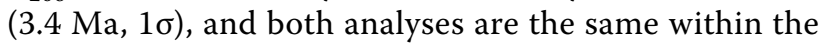
analytical uncertainty. The weighted mean $\mathrm{Pb}-\mathrm{Pb}$ age is $4348.5 \pm 4.8 \mathrm{Ma}(2 \sigma)$ with a mean square weighted deviation $(\mathrm{MSWD})=0.70$ and probability $=0.40$.

\section{Discussion}

\subsection{Accuracy and uncertainty of EPMA dating}

Zirconolite is a common accessary mineral phase, characterized by a large variation of chemical composition even for major elements $(\mathrm{Zr}, \mathrm{Ca}$, and $\mathrm{Ti})$ due to extensive substitutions under different formation conditions (Giere et al. 1998; Hurai et al. 2018; Norman and Nemchin 2014; Rasmussen et al. 2008; Seddio et al. 2013; Williams et al. 2001; Williams and Giere 1996). For $U$ and Th, they mainly substitute $\mathrm{Zr}$ to a concentration level which can be estimated by EPMA analyses. According to the U, Th, and $\mathrm{Pb}$ composition reported in previous literatures and our study, it is evidenced that zirconolite is a good candidate for EPMA chemical dating.
Generally, our EPMA chemical $\mathrm{U}-\mathrm{Th}-\mathrm{Pb}$ age of $4540 \pm 340 \mathrm{Ma}(2 \sigma)$ is somewhat older than that of NanoSIMS $\mathrm{Pb}-\mathrm{Pb}$ age of $4348.5 \pm 4.8 \mathrm{Ma}$, but still includes the NanoSIMS result within the analytical uncertainty. The upper limit of chemical age is higher than the age of the Moon, making it meaningless. Its lower limit includes the $\mathrm{Pb}-\mathrm{Pb}$ age result, making it an acceptable result but with poor accuracy. As for analytical uncertainty, the $2 \sigma$ relative deviation of chemical age is $7.6 \%$, which is consistent with $7.2 \%$ of Apollo zirconolite chemical age reported by Seddio et al. (2013), but significantly poor than $2.3 \%$ in Rajesh et al. (2006). This is mainly because the terrestrial zirconolites in Rajesh et al. (2006) contain extremely high contents of $\mathrm{UO}_{2}$ (6.51-9.64 wt\%), $\mathrm{ThO}_{2}(3.43-4.05 \mathrm{wt} \%)$ and $\mathrm{PbO}$ (0.50-0.72 wt\%), leading to low instrumental counting statistics error. Thus, in order to increase age precision for zirconolite with low $\mathrm{UO}_{2}, \mathrm{ThO}_{2}$, and $\mathrm{PbO}$, extend of peak counting time to improve the statistics for these elements is of great significance. Regarding the poor accuracy of chemical age, an increase of 0.03 wt $\%$ in the $U$ or a decrease of $0.03 \mathrm{wt} \%$ in the $\mathrm{Pb}$ would be enough to make the EPMA date correspond to the NanoSIMS date. However, both $0.03 \mathrm{wt} \%$ for $\mathrm{U}$ and 0.03 wt $\%$ for $\mathrm{Pb}$ are larger than the $2 \sigma$ standard deviation for five analyses. This indicates that there is a small systematic deviation for our EPMA analyses compared with the NanoSIMS $\mathrm{Pb}-\mathrm{Pb}$ dating, resulting the higher $\mathrm{U}-\mathrm{Th}-\mathrm{Pb}$ chemical age for zirconolite. In order to eliminate this systematic deviation, more elements selected for analyses such as HREEs, Hf, and $\mathrm{Nb}$ are necessary to make the total content closer to $100 \mathrm{wt} \%$. More careful elements interference correction for these unselected elements with high concentration on $\mathrm{U}$, Th and $\mathrm{Pb}$, such as the potential interference of $\mathrm{Ho} L_{1}$ on $\mathrm{Th} M_{\alpha}, \mathrm{Ho} L_{\alpha}$ on $\mathrm{UM}_{\beta}$, need to be considered and corrected in future lunar samples analyses. In addition, the possible effects of primary and secondary florescence of

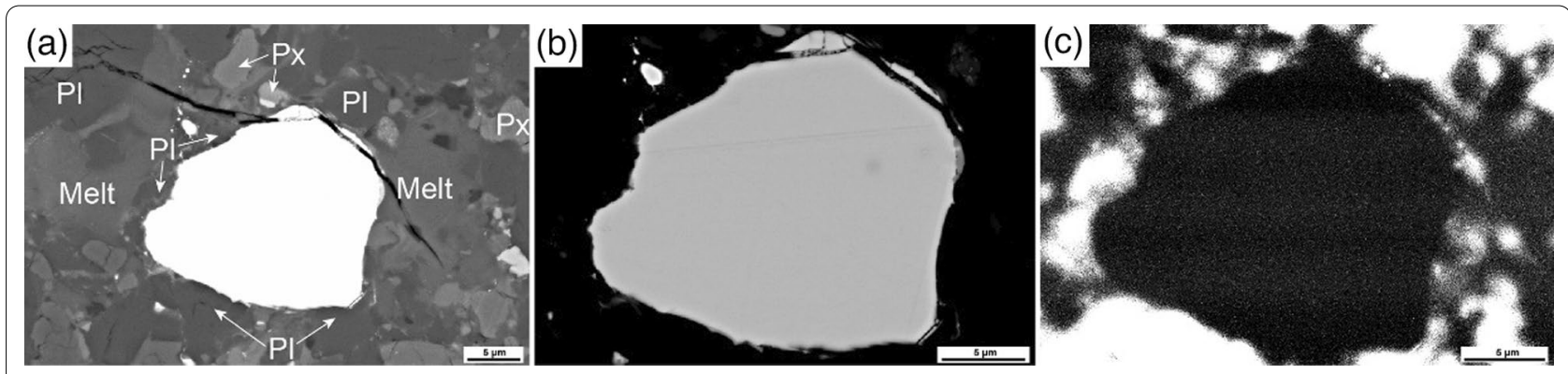

Fig. 1 The occurrence of zirconolite grain from NWA 4485. a BSE image of the zirconolite grain, occurring as a mineral fragment in matrix of the lunar regolith breccia. This grain is surrounded by plagioclase (PI), pyroxene (Px), and silicate melts (Melt). b Contrast-enhanced backscattered image of the grain, showing a homogeneous composition. c The grain is dark in CL image, showing no trace elements heterogeneity or dislocation 
Table 1 EPMA analyses of the zirconolite grain from NWA 4485, in wt\%

\begin{tabular}{|c|c|c|c|c|c|c|}
\hline & Point \#1 & Point \#2 & Point \#3 & Point \#4 & Point \#5 & Average \\
\hline $\mathrm{MgO}$ & 0.45 & 0.43 & 0.43 & 0.43 & 0.45 & 0.44 \\
\hline $\mathrm{Al}_{2} \mathrm{O}_{3}$ & 0.52 & 0.52 & 0.52 & 0.52 & 0.52 & 0.52 \\
\hline $\mathrm{SiO}_{2}$ & 0.13 & 0.17 & 0.18 & 0.19 & 0.12 & 0.16 \\
\hline $\mathrm{CaO}$ & 7.84 & 7.83 & 7.85 & 8.09 & 7.89 & 7.90 \\
\hline $\mathrm{TiO}_{2}$ & 35.1 & 35.0 & 34.9 & 35.2 & 35.0 & 35.0 \\
\hline $\mathrm{FeO}$ & 5.86 & 5.86 & 5.81 & 5.71 & 5.77 & 5.80 \\
\hline $\mathrm{Y}_{2} \mathrm{O}_{3}$ & 4.46 & 4.40 & 4.38 & 4.42 & 4.38 & 4.41 \\
\hline $\mathrm{ZrO}_{2}$ & 36.6 & 36.4 & 36.5 & 36.5 & 35.9 & 36.4 \\
\hline $\mathrm{La}_{2} \mathrm{O}_{3}$ & 0.10 & 0.10 & 0.07 & 0.09 & 0.10 & 0.09 \\
\hline $\mathrm{Ce}_{2} \mathrm{O}_{3}$ & 0.78 & 0.75 & 0.74 & 0.81 & 0.76 & 0.77 \\
\hline $\mathrm{Nd}_{2} \mathrm{O}_{3}$ & 1.17 & 1.17 & 1.17 & 1.19 & 1.20 & 1.18 \\
\hline $\mathrm{Sm}_{2} \mathrm{O}_{3}$ & 0.48 & 0.49 & 0.49 & 0.52 & 0.47 & 0.49 \\
\hline $\mathrm{Gd}_{2} \mathrm{O}_{3}$ & 0.74 & 0.75 & 0.76 & 0.77 & 0.77 & 0.76 \\
\hline $\mathrm{PbO}$ & 0.47 & 0.46 & 0.43 & 0.49 & 0.44 & 0.46 \\
\hline $\mathrm{ThO}_{2}$ & 0.64 & 0.64 & 0.64 & 0.64 & 0.63 & 0.64 \\
\hline $\mathrm{UO}_{2}$ & 0.24 & 0.25 & 0.25 & 0.23 & 0.23 & 0.24 \\
\hline Total & 95.6 & 95.2 & 95.1 & 95.8 & 94.6 & 95.3 \\
\hline $\mathrm{Pb}$ & 0.44 & 0.43 & 0.40 & 0.46 & 0.41 & 0.43 \\
\hline Th & 0.57 & 0.56 & 0.57 & 0.56 & 0.55 & 0.56 \\
\hline$U$ & 0.21 & 0.22 & 0.22 & 0.20 & 0.21 & 0.21 \\
\hline Age (Ma) & 4610 & 4466 & 4353 & 4760 & 4483 & \\
\hline SD & 380 & 381 & 395 & 371 & 393 & \\
\hline \multicolumn{7}{|c|}{ Atomic ratios based on 7 atoms of oxygen } \\
\hline Al & 0.039 & 0.039 & 0.039 & 0.039 & 0.040 & 0.039 \\
\hline Si & 0.009 & 0.011 & 0.012 & 0.012 & 0.008 & 0.010 \\
\hline $\mathrm{Ca}$ & 0.537 & 0.538 & 0.540 & 0.553 & 0.545 & 0.543 \\
\hline $\mathrm{Ti}$ & 1.689 & 1.690 & 1.686 & 1.688 & 1.698 & 1.690 \\
\hline $\mathrm{Fe}$ & 0.313 & 0.314 & 0.312 & 0.304 & 0.311 & 0.311 \\
\hline Y & 0.152 & 0.150 & 0.150 & 0.150 & 0.150 & 0.150 \\
\hline $\mathrm{Zr}$ & 1.140 & 1.138 & 1.142 & 1.135 & 1.129 & 1.137 \\
\hline La & 0.002 & 0.002 & 0.002 & 0.002 & 0.002 & 0.002 \\
\hline $\mathrm{Ce}$ & 0.018 & 0.018 & 0.017 & 0.019 & 0.018 & 0.018 \\
\hline $\mathrm{Nd}$ & 0.027 & 0.027 & 0.027 & 0.027 & 0.028 & 0.027 \\
\hline Sm & 0.011 & 0.012 & 0.012 & 0.012 & 0.011 & 0.012 \\
\hline Gd & 0.016 & 0.016 & 0.016 & 0.016 & 0.016 & 0.016 \\
\hline $\mathrm{Pb}$ & 0.008 & 0.008 & 0.007 & 0.008 & 0.008 & 0.008 \\
\hline Th & 0.009 & 0.009 & 0.009 & 0.009 & 0.009 & 0.009 \\
\hline U & 0.003 & 0.004 & 0.004 & 0.003 & 0.003 & 0.003 \\
\hline Total & 4.017 & 4.016 & 4.016 & 4.020 & 4.020 & 4.018 \\
\hline
\end{tabular}

SD standard deviation

neighboring phases might also be a potential factor for the poor accuracy. In our work, the neighboring phases of zirconolite are all silicates or silicate melts with negligible $\mathrm{K}$ concentration. The $0.16 \mathrm{wt} \% \mathrm{SiO}_{2}$ contents of our analyses are low and within the range of $\mathrm{SiO}_{2} \mathrm{com}-$ position for lunar zirconolite (up to $1.9 \mathrm{wt} \%$ but most less than $0.3 \mathrm{wt} \%$; Williams and Giere 1996). Therefore, there are little florescence effects and negligible $\mathrm{K} K_{\alpha}$ interference on $\mathrm{UM}_{\beta}$ from neighboring phases in our analyses.

For zirconolite with younger ages, their $\mathrm{Pb}$ concentration depends both on its $\mathrm{U}$, Th concentrations and on their ages. Due to low initial content of $\mathrm{Pb}$ for zirconolite, most contribution of $\mathrm{Pb}$ comes from the decay of 


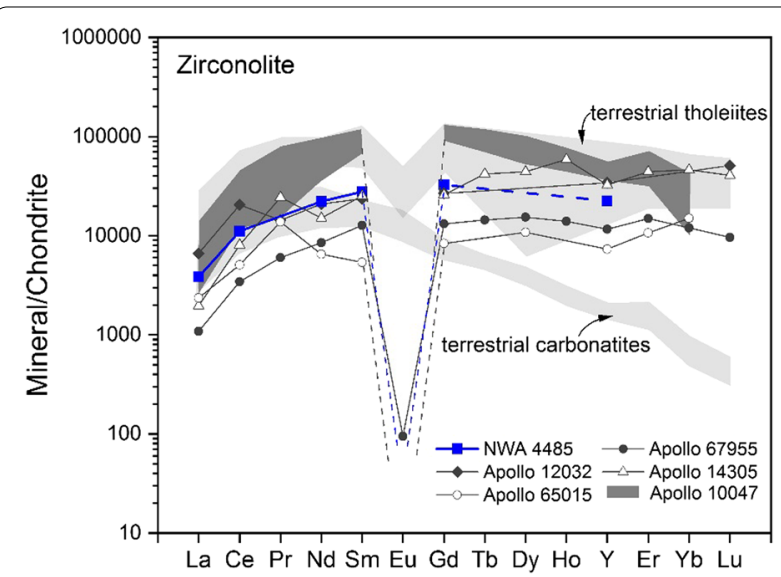

Fig. 2 Chondrite-normalized REE pattern of zirconolite from NWA 4485. It is compared with Apollo lunar zirconolites (Norman and Nemchin 2014; Rasmussen et al. 2008; Seddio et al. 2013) and terrestrial grains from tholeiites (Rasmussen et al. 2008) and carbonatites (Wu et al. 2010). The Eu composition in our grain is predicted to be lower than $100 \times \mathrm{Cl}$ based on Apollo lunar zirconolite studies

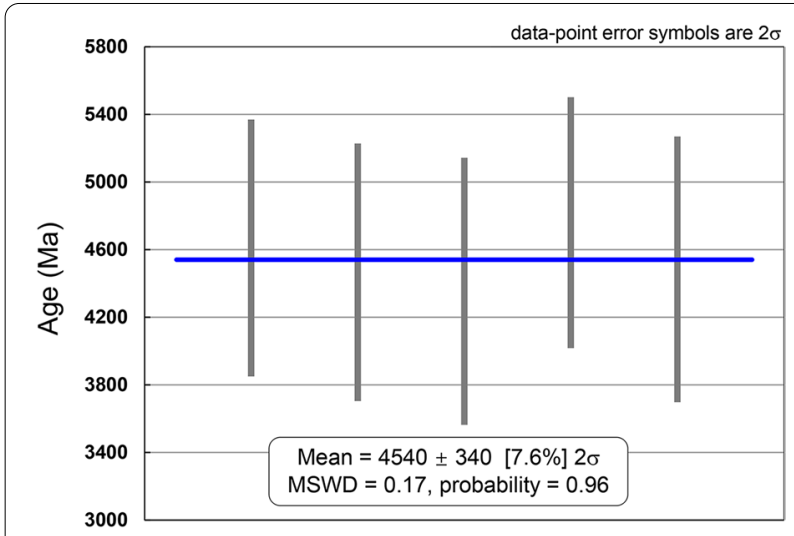

Fig. 3 Weighted mean U-Th-Pb EPMA chemical ages of zirconolite in NWA 4485

$\mathrm{U}$ and Th. Therefore, crystallizing from high U, Th concentration magma melts can also lead to high radiogenic $\mathrm{Pb}$ content even with younger ages. As zirconolite from Apollo 12 sample 12,032 granite fragment reported in Seddio et al. (2013), it contains higher U, Th, and Pb concentrations than our zirconolite from NWA 4485 even with younger age of $3.9 \pm 0.3 \mathrm{Ga}$. Therefore, for lunar zirconolite with younger ages, crystallized from a $\mathrm{U}$, Th -rich source region, such as PKT area, will also make it a potential candidate for EPMA chemical dating.

\subsection{Accuracy and uncertainty of NanoSIMS Pb-Pb dating} In contrast, due to the high contents of $\mathrm{Pb}$ and $\mathrm{U}$ compared with zircon and baddeleyite, the NanoSIMS $\mathrm{Pb}-\mathrm{Pb}$ age of zirconolite has a remarkable precision of $0.11 \%$, showing that zirconolite is an ideal mineral phase for isotopic $\mathrm{Pb}-$ $\mathrm{Pb}$ dating. The weighted average age of $4348.5 \pm 4.8 \mathrm{Ma}$ $(2 \sigma)$ is consistent with the age of $4352 \pm 10 \mathrm{Ma}$ of NWA 4485 in Arai et al. (2010) and 4344 \pm 14 Ma reported of its paired meteorite NWA 4472 in Joy et al. (2011). In addition, the negligible common $\mathrm{Pb}$ in zirconolite measured by NanoSIMS confirmed the assumption that all $\mathrm{Pb}$ is radiogenic in zirconolite. The NanoSIMS analysis on zirconolite demonstrated that it can be used to date ancient rocks using a very small ion beam with a high precision of few million years in ${ }^{207} \mathrm{~Pb} /{ }^{206} \mathrm{~Pb}$ ratios superior to that of the coexisting zircon and baddeleyite.

\subsection{REE pattern of zirconolite}

Lunar zirconolite crystallized at a late stage from interstitial in the lunar basalts (Busche et al. 1972) and is an accessory mineral able to accommodate many incompatible elements, such as REE, U, Th Zr, Hf, like zircon. As such, it has the potential for playing a significant role in the petrological/geochemical evolution of these rocktypes in which it crystallized. For example, several studies have provided evidence that zirconolite can reflect changes in the composition of the fluid during its evolutionary history, both in metasomatic system (Williams and Giere 1988, 1996), and in magmatic fractional process (Platt et al. 1987). For our analyses, the REE pattern shown in Fig. 3 displays apparent negative Eu anomaly, which indicates that this zirconolite grain formed after plagioclase as plagioclase is the main sink of Eu due to $\mathrm{Eu}^{2+}$ substitution for $\mathrm{Ca}^{2+}$ during crystallization.

\section{Implication}

Our result demonstrates the reliability and potential of EPMA U-Th-Pb dating of lunar zirconolite, which is a non-destructive, quick, and high-spatial resolution

Table $2 \mathrm{~Pb}$ isotopic data of zirconolite in NWA 4485 obtained by NanoSIMS

\begin{tabular}{|c|c|c|c|c|c|c|c|c|}
\hline Spot \# & ${ }^{204} \mathrm{~Pb} /{ }^{206} \mathrm{~Pb}$ & $1 \sigma(\%)$ & ${ }^{207} \mathrm{~Pb} /{ }^{206} \mathrm{~Pb}$ & $1 \sigma(\%)$ & ${ }^{207} \mathrm{~Pb}^{*} /{ }^{206} \mathrm{~Pb}^{*}$ & $1 \sigma(\%)$ & ${ }^{204} \mathrm{~Pb} /{ }^{206} \mathrm{~Pb}$ Age & $\pm(1 \sigma)(\mathrm{Ma})$ \\
\hline 1 & 0.000003 & 44 & 0.53863 & 0.23 & 0.53861 & 0.23 & 4350.5 & 3.4 \\
\hline 2 & 0.000014 & 24 & 0.53722 & 0.23 & 0.53714 & 0.23 & 4346.5 & 3.4 \\
\hline
\end{tabular}

${ }^{207} \mathrm{~Pb}^{*} / 206 \mathrm{~Pb}^{*}$ ratios are ${ }^{204} \mathrm{~Pb}$-corrected for terrestrial common $\mathrm{Pb}$ 
technique. In addition, zirconolite contains high $\mathrm{Pb}$, $\mathrm{U}$ and $\mathrm{Th}$, and it was commonly reported as a ubiquitous trace mineral especially in lunar KREEPy basalts (Day et al. 2006; Lovering and Wark 1971; Rasmussen et al. 2008; Wark et al. 1973; Zeigler et al. 2005; Zhang et al. 2010). The recently returned Chang'E- 5 samples are expected to be young mare basalt with the age of 1.2-2.2 Ga and rich in KREEP component (Hiesinger et al. 2010; Qian et al. 2018; Zhao et al. 2017). Therefore, the development of EPMA U-Th-Pb dating is appropriate for a quick prelude dating survey of the new lunar sample with no sample damage, and also for zirconolite grains less than $2 \mu \mathrm{m}$ which are too small for SIMS. Besides, the simultaneously acquired REE data can also help to study the geochemical evolution of the Chang'E-5 rock in which it crystallized.

\section{Abbreviations}

NanoSIMS: nanometer secondary ion mass spectrometry; SIMS: secondary ion mass spectrometry; EPMA: electron probe microanalyzer; REE: rare earth elements; KREEP: potassium, rare earth element, and phosphorus; BSE: backscatter electron; CL: cathodoluminescence; MSWD: mean square weighted deviates.

\section{Supplementary Information}

The online version contains supplementary material available at https://doi. org/10.1186/s40645-021-00446-3.

Additional file 1. Fig. S1. Full range WDS Wavescans of the large zirconolite grain acquired with TAP (a), LPET (b, d), and LLiF (c) diffractors. The enlarged map of blue rectangle in (b) are displayed in (d), showing the details of low cps peaks. Fig. S2. Monte Carlo simulations of the interaction volumes of electrons and generation volumes of $X$-rays in zirconolite generated using Casino (Drouin et al., 2007) at $20 \mathrm{kV}$ with a focused beam. The density of zirconolite is defined as $4.8 \mathrm{~g} / \mathrm{cm}^{3} .1 * 10^{4}$ electron trajectories were calculated and displayed. In order to acquire the smallest beam size, we plotted the correlation between electrons and $X$-rays volumes and EPMA beam diameter (a). The smallest XY dimensional diameter of electrons and $X$-rays of $1.3 \mu \mathrm{m}$ was acquired when the focused EPMA beam diameter are no more than $200 \mathrm{~nm}$. (b) The interaction volumes of electrons and generation volumes of X-rays at $20 \mathrm{kV}$ with $200 \mathrm{~nm}$ EPMA beam diameter. (c) The XY dimensional energy distribution with $20 \mathrm{kV}$ voltage and $200 \mathrm{~nm}$ beam size. (d) The $Y Z$ dimensional energy distribution with $20 \mathrm{kV}$ voltage and $200 \mathrm{~nm}$ beam size shows 95\% of energy are distributed less than $1.5 \mu \mathrm{m}$ in depth.

\section{Acknowledgements}

We thank Dr. Yuchen Xu, Di Zhang, and Jing Li for their kind assistance in our experiments and data processing. We are also grateful to the Associate Editor Dr. Noriko Kita and two reviewers (Dr. John Bowles and one anonymous reviewer) for their constructive suggestions on the manuscript.

\section{Authors' contributions}

YL proposed the topic, conceived and designed the study. NW carried out the experimental study and wrote the manuscript. TZ helped to construct and modify the manuscript. QM conducted the EPMA analysis and helped in the data interpretation. JH helped to carry out the NanoSIMS analysis. All authors read and approved the final manuscript.
Funding

This work was supported by Key Research Program of Frontier Sciences, CAS (QYZDJ-SSW-DQC001).

\section{Availability of data and materials}

The datasets supporting the conclusions of this article are included within the article.

\section{Declarations}

\section{Competing interests}

The authors declare that they have no competing interest.

\section{Author details}

${ }^{1}$ Key Laboratory of Earth and Planetary Physics, Institute of Geology and Geophysics, Chinese Academy of Sciences, Beijing 100029, China. ${ }^{2}$ University of Chinese Academy of Sciences, Beijing 100049, China. ${ }^{3}$ State Key Laboratory of Lithospheric Evolution, Institute of Geology and Geophysics, Chinese Academy of Sciences, Beijing 100029, China.

Received: 14 April 2021 Accepted: 2 September 2021

Published online: 13 September 2021

\section{References}

Arai T, Misawa K, Tomiyama T, Yoshitake M, Irving A (2009) Constraints on lunar KREEP magmatism: a variety of KREEP basalt derivatives in lunar meteorite NWA 4485. In: Abstract \#2292 of the 40th lunar and planetary science conference, The Woodlands, Texas, 23-27 Mar 2009

Arai T, Yoshitake M, Tomiyama T, Niihara T, Yokoyama T, Kaiden H, Misawa K, Irving A (2010) Support for a prolonged KREEP magmatism: U-Pb age dating of zircon and baddeleyite in Lunar Meteorite NWA 4485. In: Abstract \#2379 of the 41st lunar and planetary science conference, The Woodlands, Texas, 1-5 Mar 2010

Bowles J (1990) Age dating of individual grains of uraninite in rocks from electron microprobe analyses. Chem Geol 83(1-2):47-53

Bowles JFW (2015) Age dating from electron microprobe analyses of U, Th, and $\mathrm{Pb}$ : geological advantages and analytical difficulties. Microsc Microanal 21(5):1114-1122. https://doi.org/10.1017/s1431927615000446

Busche F, Prinz M, Keil K, Kurat G (1972) Lunar zirkelite: a uranium-bearing phase. Earth Planet Sci Lett 14(3):313-321

Chatterjee A, Das K, Bose S, Ganguly P, Hidaka H (2017) Zircon U-Pb SHRIMP and monazite EPMA $U$-Th-total Pb geochronology of granulites of the western boundary, Eastern Ghats Belt, India: a new possibility for Neoproterozoic exhumation history. Geol Soc Lond Spec Publ 457(1):105-140. https://doi.org/10.1144/sp457.1

Cocherie A, Legendre O (2007) Potential minerals for determining U-Th-Pb chemical age using electron microprobe. Lithos 93:288-309. https://doi. org/10.1016/j.lithos.2006.03.069

Cross A, Jaireth S, Rapp R, Armstrong R (2011) Reconnaissance-style EPMA chemical U-Th-Pb dating of uraninite. Aust J Earth Sci 58(6):675-683. https://doi.org/10.1080/08120099.2011.598190

Day JM, Taylor LA, Floss C, Patchen AD, Schnare DW, Pearson DG (2006) Comparative petrology, geochemistry, and petrogenesis of evolved, low-Ti lunar mare basalt meteorites from the LaPaz Icefield, Antarctica. Geochim Cosmochim Acta 70(6):1581-1600. https://doi.org/10.1016/j. gca.2005.11.015

Downes PJ, Dunkley DJ, Fletcher IR, McNaughton NJ, Rasmussen B, Jaques AL, Verrall M, Sweetapple MT (2016) Zirconolite, zircon and monazite(Ce) U-Th-Pb age constraints on the emplacement, deformation and alteration history of the Cummins Range Carbonatite Complex, Halls Creek Orogen, Kimberley region, Western Australia. Mineral Petrol 110(2-3):199-222. https://doi.org/10.1007/s00710-015-0418-y

Drouin D, Couture AR, Joly D, Tastet X, Aimez V, Gauvin R (2007) CASINO V2.42: a fast and easy-to-use modeling tool for scanning electron microscopy and microanalysis users. Scanning 29(3):92-101. https:// doi.org/10.1002/sca.20000 
Giere R, Williams CT, Lumpkin GR (1998) Chemical characteristics of natural zirconolite. Schweiz Mineral Petrogr Mitt 78(3):433-459. https://doi. org/10.5169/seals-59299

Hao J, Yang W, Hu S, Li R, Lin Y (2021) Submicron spatial resolution Pb-Pb and $\mathrm{U}-\mathrm{Pb}$ dating by NanoSIMS equipped with the new radio-frequency ion source. J Anal at Spectrom 36:1625-1633. https://doi.org/ 10.1039/D1JA00085C

Hazarika P, Mishra B, Ozha MK, Pruseth KL (2017) An improved EPMA analytical protocol for $\mathrm{U}-\mathrm{Th}-\mathrm{Pb}$ total dating in xenotime: age constraints from polygenetic Mangalwar Complex, Northwestern India. Geochemistry 77(1):69-79. https://doi.org/10.1016/j.chemer.2017.01.010

Hiesinger H, Head JW III, Wolf U, Jaumann R, Neukum G (2010) Ages and stratigraphy of lunar mare basalts in Mare Frigoris and other nearside maria based on crater size-frequency distribution measurements. J Geophys Res Planets. https://doi.org/10.1029/2009JE003380

Hurai V, Huraiova M, Gajdosova M, Konecny P, Slobodnik M, Siegfried PR (2018) Compositional variations of zirconolite from the Evate apatite deposit (Mozambique) as an indicator of magmatic-hydrothermal conditions during post-orogenic collapse of Gondwana. Mineral Petrol 112(3):279-296. https://doi.org/10.1007/s00710-017-0538-7

Joy K, Burgess R, Hinton R, Fernandes V, Crawford IA, Kearsley A, Irving A (2011) Petrogenesis and chronology of lunar meteorite Northwest Africa 4472: a KREEPy regolith breccia from the Moon. Geochim Cosmochim Acta 75(9):2420-2452. https://doi.org/10.1016/j.gca.2011. 02.018

Korotev RL (1996) A self-consistent compilation of elemental concentration data for 93 geochemical reference samples. Geostand Newsl 20(2):217-245. https://doi.org/10.1111/j.1751-908X.1996.tb00185.x

Lovering J, Wark D (1971) Uranium-enriched phases in Apollo 11 and Apollo 12 basaltic rocks. Paper presented at the second Lunar Science Conference, Houston, Texas, 11-14 Jan 1971

Ludwig KR (2003) ISOPLOT 3.0: a geochronological toolkit for microsoft excel, vol 4. Berkeley Geochronology Center Special Publication, Berkeley, p 70

Merlet C (1994) An accurate computer correction program for quantitative electron probe microanalysis. Microchim Acta 114(1):363-376. https:// doi.org/10.1007/BF01244563

Montel JM, Foret S, Veschambre M, Nicollet C, Provost A (1996) Electron microprobe dating of monazite. Chem Geol 131(1-4):37-53. https://doi.org/10. 1016/0009-2541(96)00024-1

Norman MD, Nemchin AA (2014) A 4.2 billion year old impact basin on the Moon: U-Pb dating of zirconolite and apatite in lunar melt rock 67955. Earth Planet Sci Lett 388:387-398

Platt RG, Wall F, Williams CT, Woolley AR (1987) Zirconolite, chevkinite and other rare earth minerals from nepheline syenites and peralkaline granites and syenites of the Chilwa Alkaline Province. Malawi Mineral Mag 51(360):253-263

Pyle JM, Spear FS, Wark DA, Daniel CG, Storm LC (2005) Contributions to precision and accuracy of monazite microprobe ages. Am Miner 90(4):547577. https://doi.org/10.2138/am.2005.1340

Qian YQ, Xiao L, Zhao SY, Zhao JN, Huang J, Flahaut J, Martinot M, Head JW Hiesinger H, Wang GX (2018) Geology and scientific significance of the Rumker Region in Northern Oceanus Procellarum: China's Chang'E-5 landing region. J Geophys Res Planets 123(6):1407-1430. https://doi.org/ 10.1029/2018je005595

Rajesh VJ, Yokoyama K, Santosh M, Arai S, Oh CW, Kim SW (2006) Zirconolite and baddeleyite in an ultramafic suite from Southern India: early ordovician carbonatite-type melts associated with extensional collapse of the Gondwana crust. J Geol. https://doi.org/10.1086/499571

Rasmussen B, Fletcher IR (2004) Zirconolite: a new U-Pb chronometer for mafic igneous rocks. Geology 32(9):785-788. https://doi.org/10.1130/ g20658.1

Rasmussen B, Fletcher IR, Muhling JR (2008) Pb/Pb geochronology, petrography and chemistry of Zr-rich accessory minerals (zirconolite, tranquillityite and baddeleyite) in mare basalt 10047. Geochim Cosmochim Acta 72(23):5799-5818. https://doi.org/10.1016/j.gca.2008.09.010

Rasmussen B, Mueller AG, Fletcher IR (2009) Zirconolite and xenotime U-Pb age constraints on the emplacement of the Golden Mile Dolerite sill and gold mineralization at the Mt Charlotte mine, Eastern Goldfields Province,
Yilgarn Craton, Western Australia. Contrib Miner Petrol 157(5):559-572. https://doi.org/10.1007/s00410-008-0352-7

Seddio SM, Jolliff BL, Korotev RL, Carpenter PK (2014) Thorite in an Apollo 12 granite fragment and age determination using the electron microprobe. Geochim Cosmochim Acta 135:307-320. https://doi.org/10.1016/j.gca. 2014.03.020

Seddio SM, Jolliff BL, Korotev RL, Zeigler RA (2013) Petrology and geochemistry of lunar granite 12032,366-19 and implications for lunar granite petrogenesis. Am Miner 98(10):1697-1713. https://doi.org/10.2138/am. 2013.4330

Stacey JS, Kramers JD (1975) Approximation of terrestrial lead isotope evolution by a two-stage model. Earth Planet Sci Lett 26(2):207-221. https:// doi.org/10.1016/0012-821X(75)90088-6

Steiger RH, Jäger E (1977) Subcommission on geochronology: convention on the use of decay constants in geo- and cosmochronology. Earth Planet Sci Lett 36(3):359-362. https://doi.org/10.1016/0012-821X(77)90060-7

Suzuki K, Adachi M (1991a) The chemical Th-U-Total Pb isochron ages of zircon and monazite from the Gray Granite of the Hida Terrane, Japan. J Earth Sci Nagoya Univ 38:11-37

Suzuki K, Adachi M (1991b) Precambrian provenance and Silurian metamorphism of the Tsubonosawa paragneiss in the South Kitakami Terrane, Northeast Japan, revealed by the chemical Th-U-total $\mathrm{Pb}$ isochron ages of monazite, zircon and xenotime. Geochem J 25(5):357-376. https://doi. org/10.2343/geochemj.25.357

Suzuki K, Adachi M, Kajizuka I (1994) Electron microprobe observations of Pb diffusion in metamorphosed detrital monazites. Earth Planet Sci Lett 128(3):391-405. https://doi.org/10.1016/0012-821X(94)90158-9

Wark DA, Reid AF, Lovering JF, Goresy AE (1973) Zirconolite (versus zirkelite) in Lunar Rocks. In: Abstracts of the fourth lunar and planetary science conference, vol 4, pp 764-766, Houston, Texas, 5-8 March 1973

Williams CT, Giere R (1988) Metasomatic zonation of REE in zirconolite from a marble skarn at the Bergell contact aureole (Switzerland/Italy). Schweiz Mineral Petrogr Mitt 68:133-140

Williams CT, Giere R (1996) Zirconolite: a review of localities worldwide, and a compilation of its chemical compositions. Bull Nat Hist Mus Lond 52(1): $1-24$

Williams CT, Bulakh AG, Gieré R, Lumpkin GR, Mariano AN (2001) Alteration features in natural zirconolite from carbonatites. MRS Online Proc Libr 663(1):945. https://doi.org/10.1557/PROC-663-945

Wu F-Y, Yang Y-H, Mitchell RH, Bellatreccia F, Li Q-L, Zhao Z-F (2010) In situ $\mathrm{U}-\mathrm{Pb}$ and $\mathrm{Nd}-\mathrm{Hf}-(\mathrm{Sr})$ isotopic investigations of zirconolite and calzirtite. Chem Geol 277(1):178-195. https://doi.org/10.1016/j.chemgeo.2010.08. 007

Yang W, Lin YT, Zhang JC, Hao JL, Shen WJ, Hu S (2012) Precise micrometresized $\mathrm{Pb}-\mathrm{Pb}$ and $\mathrm{U}-\mathrm{Pb}$ dating with NanoSIMS. J Anal Spectrom 27(3):479-487. https://doi.org/10.1039/c2ja10303f

Yonemura K, Osanai Y, Nakano N, Adachi T, Charusiri P, Zaw TN (2013) EPMA UTh-Pb monazite dating of metamorphic rocks from the Mogok Metamorphic Belt, central Myanmar. J Mineral Petrol Sci 108(3):184-188

Zeigler RA, Korotev RL, Jolliff BL, Haskin LA (2005) Petrography and geochemistry of the LaPaz Icefield basaltic lunar meteorite and source crater pairing with Northwest Africa 032. Meteorit Planet Sci 40(7):1073-1101. https:// doi.org/10.1111/j.1945-5100.2005.tb00174.x

Zhang A, Hsu W, Li Q, Liu Y, Jiang Y, Tang G (2010) SIMS Pb/Pb dating of Zr-rich minerals in lunar meteorites Miller Range 05035 and LaPaz Icefield 02224: implications for the petrogenesis of mare basalt. Sci China Earth Sci 53(3):327-334. https://doi.org/10.1007/s11430-010-0041-z

Zhao JN, Xiao L, Qiao L, Glotch TD, Huang Q (2017) The Mons Rumker volcanic complex of the Moon: a candidate landing site for the Chang'E-5 mission. J Geophys Res-Planets 122(7):1419-1442. https://doi.org/10.1002/2016j e005247

\section{Publisher's Note}

Springer Nature remains neutral with regard to jurisdictional claims in published maps and institutional affiliations. 